\author{
(1) Özlem Soyer, \\ (D) Pakize Özyürek, \\ (1) Meryem Yavuz Van Giersbergen
}

\section{The Effect of Endotracheal Tube Cuff Pressure Control Training on Nurses' Knowledge Level}

\author{
Endotrakeal Tüp Kaf Basınç Kontrol Eğitiminin \\ Hemşirelerin Bilgi Düzeyine Etkisi
}

Received/Geliş Tarihi : 07.03.2019

Accepted/Kabul Tarihi : 27.09.2019

${ }^{\circ}$ Copyright 2019 by Turkish Society of Intensive Care Turkish Journal of Intensive Care published by Galenos Publishing House.

Özlem Soyer, Pakize Özyürek

Afyonkarahisar University of Health Sciences, Faculty of Health Sciences, Nursing Department, Afyonkarahisar, Turkey

Meryem Yavuz Van Giersbergen

Ege University, Nursing Faculty, Department of Surgical Nursing, Izmir, Turkey

Özlem Soyer MD (我),

Afyonkarahisar University of Health Sciences, Faculty of Health Sciences, Nursing Department, Afyonkarahisar, Turkey

E-mail : ozlemm_soyer@hotmail.com

Phone : : +90 5534853871

ORCID ID : orcid.org/0000-0002-9272-2400

\begin{abstract}
Objective: This study was designed to investigate the effect of endotracheal tube cuff pressure training on the knowledge level of intensive care nurses.

Materials and Methods: This quasi-experimental study was conducted in August 2017 with 32 nurses working in eight different intensive care units of a university hospital. Data were collected using structured and self-administered 8-item Sociodemographic and Occupational Characteristics Form, and a 20-item Endotracheal Tube Cuff Pressure Control Knowledge Level Evaluation Form. Results: The mean age of the participating nurses was $25.80 \pm 5.31$ years and $59.4 \%$ of them were female. The mean work experience of the nurses was $5.87 \pm 4.44$ years, while their mean ICU experience was $4.37 \pm 3.85$ years. After endotracheal tube cuff pressure training, the mean knowledge score of the nurses was found to be significantly higher $(17.90 \pm 1.71)$ than that of pre-training score $(10.90 \pm 2.73)(Z=-4.942, p<0.001)$.

Conclusion: It was found that endotracheal tube cuff pressure training enhanced the knowledge level of intensive care nurses, and the views and recommendations of the nurses were positive. It is advised to increase the training of ICU nurses to enhance their knowledge and skills regarding endotracheal tube cuff pressure control.
\end{abstract}

Keywords: Cuff Pressure Control, Training, Intensive Care, Nursing

ÖZ Amaç: Yoğun bakımda çalışan hemşirelere endotrakeal tüp kaf basıncı kontrolüne ilișkin düzenlenen eğitimin hemşirelerin bu konuda bilgi düzeyine etkisini incelemekti.

Gereç ve Yöntem: Yarı deneysel bu çalışma Ağustos 2017 tarihinde bir üniversite hastanesinin sekiz farkı yoğun bakım ünitelerinde çalışan 32 hemşire ile yapıldı. Veriler, yapılandııımış 8 maddelik Sosyodemografik ve Mesleki Özellikler Formu, 20 maddelik Endotrakeal Tüp Kaf Basıncı Kontrolüne Ilişkin Bilgi Düzeyi Değerlendirme Formu ile toplandı.

Bulgular: Hemşirelerin yaş ortalaması 25,80 \pm 5,31 yıl olup, \%59.4'u kadındır. Hemşirelerin ortalama çalışma süresi $5.87 \pm 4.44 \mathrm{yıl}$, yoğun bakım deneyimi ise ortalama $4.37 \pm 3.85 \mathrm{yıldı}$.

Endotrakeal tüp kaf basınç eğitimi sonrası hemşirelerin bilgi puan ortalamaları (17.90 \pm 1.71$)$, eğitim öncesi puan ortalamalarına (10.90 \pm 2.73 ) göre anlamlı derecede yüksek bulundu $(Z=-4.942, p$ $<0.001)$.

Sonuç: Endotrakeal tüp manşet basınç eğitiminin yoğun bakım hemşirelerinin bilgi düzeyini arttırdığı ve hemşirelerin görüş ve önerilerinin olumlu olduğu tespit edildi. Yoğun bakım hemşirelerinin endotrakeal tüp manşet basınç kontrolü ile ilgili bilgi ve becerilerini geliştirmeye yönelik eğitimin artırıması önerilir.

Anahtar Kelimeler: Kaf Basınç Kontrolü, Eğitim, Yoğun Bakım, Hemşirelik

\section{Introduction}

Supporting adequate ventilation/oxygenation, minimizing risk of infection, maintaining the patients' trust and comfort, monitoring and preparing the extubation criteria for patients receiving mechanical ventilator support are among the responsibilities of nurses in Intensive Care Units (ICU) (1).

While respiratory therapists are mostly responsible for endotracheal tube (ETT) and ETT cuff pressure management in US healthcare institutions, in other countries these are the 
nurses' responsibility (2). In Turkey, nurses are responsible for the control and management of the ETT cuff pressure. Maintaining the ETT cuff at a sufficient pressure is a key factor in patient care management during invasive mechanical ventilation $(3,4)$. ETT cuff pressure must be between 20-30 $\mathrm{cmH}_{2} \mathrm{O}(5-7)$.

Controlling the ETT cuff pressure is important in terms of preventing complications (1). A low ETT cuff pressure and a slight inflation of the ETT cuff is related to an inadequate distribution and aspiration of secretions in the anticipated tidal volume (2). Low ETT cuff pressure leads to secretions that accumulate in the subglottic area, advancing to the lower respiratory tract and triggering ventilator-associated pneumonia (VAP) $(3,4,8)$. When the ETT cuff pressure is kept lower than $20 \mathrm{cmH}_{2} \mathrm{O}$, the VAP risk quadruples (2).

A high ETT cuff pressure may cause mucosal ischemia (8). Also, an ETT cuff pressure increase over $30 \mathrm{cmH}_{2} \mathrm{O}$, the frequency of post-operational complications such as coughing, sore throat, hoarseness and haemoptysis increases. In addition, over ETT cuff pressure results in severe morbidity due to tracheal damage (7). Trachea stenosis is the shrinkage of the trachea's transverse diameter to below $10 \%$. Post-intubation tracheal stenosis is usually associated with the ETT cuff pressure. ETT cuff pressure being higher than the capillary perfusion pressure, which is $25-35 \mathrm{mmHg}$, is the most visible factor in tracheal stenosis (9). To minimize complications, obligatory round-the-clock monitoring and control of ETT cuff pressure has been suggested (10).

Among the methods used for controlling ETT cuff pressure are finger palpation of the pilot balloon (11), the minimal leak technique, the minimal obstructive volume technique (2), intermittent check with a manometer (3), and constant ETT cuff pressure control (12).

Studies show that nurses do not check the ETT cuff pressure and that only $11 \%-27 \%$ of ETTs have a cuff pressure that is safe (13). The ICU of the university hospital where the study was conducted adopts the technique of deflating the ETT cuff and re-filling with air using a $10 \mathrm{cc}$ injector on a two-hourly basis. Yet resting or deflating the ETT cuff and other such procedures should not be performed during ETT cuff control in order to prevent aspiration. The ETT cuff pressure should be monitored and the cuff pressure must be maintained between $20-30 \mathrm{cmH}_{2} \mathrm{O}$ (14).

With respect to the literature, it is obvious that the knowledge of ICU healthcare workers regarding ETT cuff pressure control is not adequate $(15,16)$.

\section{Materials and Methods}

\section{Sample and Setting}

This study was a one-group pretest-posttest design. The study was conducted at a university hospital in $X$ in $X$. This hospital with a capacity of 1000 beds has 8 adult intensive care units. 54 nurses employed in the ICUs of the Neurosurgery, Anesthesiology and Reanimation, Pulmonary Diseases, Internal, Neurology, Isolation, Coronary, and Cardiovascular Surgery departments of a university hospital. The study was carried out in this eight adult ICUs where the ETT cuff pressure procedure was performed on mechanically ventilated patients with finger palpation of the pilot balloon. 32 nurses who were over 18 years old, volunteered to participate in the research, and had at least 1 month of intensive care experience were included in the sample.

\section{Data Collection}

Data collection was undertaken August 2017. After receiving permission from the ethics committee and the institution, the day of training was determined in cooperation with the nursing services directorate. The participating nurses were given two training sessions on ETT cuff pressure control on August 23, 2017. The study data was obtained with face to face meetings. Nurses first signed the informed consent form. Nurses' demographic and occupational characteristics and their ETT cuff pressure control knowledge levels were measured before training. Training lasted about one hour and it was given as a presentation. ETT cuff pressure control knowledge levels of nurses' were re-evaluated after training. Finally, the opinions of the nurses about the training were taken.

Data were collected with structured and self-administered questionnaires using a 8-item demographic and occupational characteristic form, a 20-item knowledge level form and a 9-item nurses' views form. The instruments were prepared in accordance with the literature. While creating the survey, expert opinion was obtained. The instruments were prepared in Turkish.

The 8-item self-administered form consisted of demographic and occupational features. In this instrument was focused on common variable that can affect ETT cuff pressure control knowledge of nurses which included age, gender, types of nursing degrees, length of nursing experience, type of ICU, length of ICU experience, type of working shift and length of one week working. 
The 20-item knowledge level form was developed to assess the knowledge of nurses on ETT cuff pressure control by researchers. This instrument consisted of five parts: part 1: question related to normal range of ETT cuff pressure (1 item), part 2: question related to complications of ETT cuff pressure (4 items), part 3: question related to responsibility of ETT cuff pressure (1 item), part 4: question related to control methods of ETT cuff pressure (5 items), part 5: question related to affecting factors ETT cuff pressure ( 9 items). Only one item (part 1) had four answers options the range of ETT cuff pressure, "10-20 $\mathrm{cmH}_{2} \mathrm{O}$ ", "20-30 $\mathrm{cmH}_{2} \mathrm{O}$ ", "30-40 $\mathrm{cmH}_{2} \mathrm{O}$ " and "above $40 \mathrm{cmH}_{2} \mathrm{O}$ ". Another items had three answers options, "correct", "incorrect" and "do not know". While scoring, correct answers scored one point each, when incorrect answers and "do not know" options scored zero.

\section{Data Analysis}

The data obtained during the study was analyzed with the SPSS (Statistical Package for the Social Sciences Inc., New York, USA) package program. The demographic and occupational characteristics of the nurses were identified using frequency, percentage distribution, averages and standard deviation values. The Mann Whitney U Test was used to compare the pre-training and post-training average scores. In addition, to detect and identify the significance of the difference between pre- and post-training average scores for the groups, two-factor variance analysis was used for the related measurements. Correct answers to the questions on the knowledge level form were given one point each while incorrect ones were given zero points. The knowledge level scores were calculated by averaging the number of correct answers. The level of significance was accepted at $p<0.05$.

\section{Ethical Approvals}

Permission for the study was obtained from the institution where the study was conducted with decision number E.23390, dated 18.02.17. For the implementation, permission was obtained from the Board of Ethics of the Non-Invasive Clinical Research Center of the Faculty of Medicine, $X$ University, with the decision numbered 2017/6-171 and dated 02.06.17. Permission was also obtained from nurses.

\section{Results}

\section{Demographic Characteristics}

The average of the age of the participating nurses $(n=32)$ was $25.80 \pm 5.31$ years; $59.4 \%$ of them were women.
$46.9 \%(n=15)$ of the nurses had graduated from healthcare vocational high schools. $21.9 \%(n=7)$ of the nurses worked in the Neurosurgery ICU. The average work experience of the nurses was $5.87 \pm 4.44$ ( $\min$ - $\max =0-17$ ) years, while their average ICU experience was $4.37 \pm 3.85$ (min- max = $0-17)$ years. $81.2 \%(n=26)$ worked both the day and night shift. The average weekly working hours were $44.93 \pm 3.56$ ( $\min -\max =40-48$ ) hours (Table 1).

\section{Nurses' Level of Knowledge Regarding Endotracheal Cuff Pressure Control}

A statistically significant difference was found between the pre-training and post-training evaluation of the questions (16 items) related to the normal pressure range of the ETT cuff, potential complications in case of ETT cuff pressure deviating from its normal range, methods of controlling ETT cuff pressure and the factors affecting the ETT cuff pressure $(p<0.05)$. No statistically significant difference was found in terms of the aspects of leakage during positive-pressured ventilation when the ETT cuff is fully sealed, tracheal damage in case of high ETT cuff pressure, aspiration of the mouth and, if possible, the subglottic area in cases when the ETT cuff is deflated and tracheal aspiration affecting the ETT cuff pressure $(p>0.05)$. The average knowledge score of the participating nurses prior to the training was $10.90 \pm$ 2.73 , while this score rose to $17.90 \pm 1.71$ after the training. A statistically significant difference was found between the pre- and post-training regarding ETT cuff pressure control $(Z=$ $-4.942, p<0.001$ ) (Table 2).

The distribution of the pre-training and post-training correct answers to the five areas related to ETT cuff pressure control is as follows. The correct answer to the normal range of ETT cuff pressure was $20.6 \%$ vs $96.9 \%$; complications of ETT cuff pressure was $61.7 \%$ vs $84.4 \%$; responsibility of ETT cuff pressure $62.5 \%$ vs $96.9 \%$; control methods of ETT cuff pressure $46.9 \%$ vs $95.6 \%$ and affecting factors of ETT cuff pressure $58.3 \%$ vs $84.0 \%$.

\section{The Relationship between the Demographic and Occupational Characteristics of the Nurses Working in the ICUs and Their Knowledge Level of ETT Cuff Pressure Control}

The relationship between the demographic and occupational characteristics of the nurses working in the ICUs and their knowledge level of ETT cuff pressure control was investigated, and this indicated no statistically significant 


\begin{tabular}{|c|c|c|}
\hline \multirow[t]{2}{*}{ Characteristic } & $n$ & $\%$ \\
\hline & \multicolumn{2}{|c|}{ Mean \pm SD (range) } \\
\hline \multicolumn{3}{|l|}{ Age (years) } \\
\hline $18-23$ & 12 & 37.5 \\
\hline $24-29$ & 11 & 34.4 \\
\hline 30 and over & 9 & 28.1 \\
\hline$M \pm S D$, range & \multicolumn{2}{|c|}{$25.80 \pm 5.31,18-36$ years } \\
\hline \multicolumn{3}{|l|}{ Gender } \\
\hline Female & 19 & 59.3 \\
\hline Male & 13 & 40.7 \\
\hline \multicolumn{3}{|l|}{ Types of nursing degrees } \\
\hline Vocational school of health & 15 & 46.9 \\
\hline Associate degree & 3 & 9.4 \\
\hline Bachelor's degree & 9 & 28.1 \\
\hline Post-graduate degree & 5 & 15.6 \\
\hline \multicolumn{3}{|c|}{ Length of nursing experience (years) } \\
\hline $0-4$ years & 15 & 46.9 \\
\hline 5 years and over & 17 & 53.1 \\
\hline$M \pm S D$, range & \multicolumn{2}{|c|}{$5.87 \pm 4.44,1$ months- 17 years } \\
\hline \multicolumn{3}{|l|}{ Type of ICU } \\
\hline Neurosurgery & 7 & 21.9 \\
\hline $\begin{array}{l}\text { Anesthesiology and } \\
\text { Reanimation }\end{array}$ & 6 & 18.8 \\
\hline General Surgery & 5 & 15.6 \\
\hline Pulmonary Diseases & 4 & 12.5 \\
\hline Internal Diseases-Neurology & 3 & 9.4 \\
\hline Isolation & 3 & 9.4 \\
\hline Coronary & 2 & 6.2 \\
\hline Cardiovascular Surgery & 2 & 6.2 \\
\hline \multicolumn{3}{|c|}{\begin{tabular}{|l|} 
Length of ICU experience (years) \\
\end{tabular}} \\
\hline $0-4$ years & 19 & 59.3 \\
\hline 5 years and over & 13 & 40.7 \\
\hline$M \pm S D$, range & \multicolumn{2}{|c|}{$4.37 \pm 3.85,1$ months -17 years } \\
\hline \multicolumn{3}{|l|}{ Type of working shift } \\
\hline Only day shift & 5 & 15.6 \\
\hline Only night shift & 1 & 3.1 \\
\hline Day and night shift & 26 & 81.3 \\
\hline \multicolumn{3}{|c|}{ Length of one week working (hours) } \\
\hline $0-45$ hours & 16 & 50 \\
\hline 46 hours and above & 16 & 50 \\
\hline$M \pm S D$, range & \multicolumn{2}{|c|}{$44,93 \pm 3,56,40-48$ hours } \\
\hline Total & 32 & 100 \\
\hline SD = standart deviation & & \\
\hline
\end{tabular}

difference between their knowledge levels according to the nurses' age, gender, types of nursing degrees, work experience, the ICU they worked in, their position in the ICU, and the amount of time working in the ICU $(p<0.05)$ (Table 3).

\section{Discussion}

ETT cuff pressure control is an integral aspect of the airway management of the intubated patients receiving mechanical ventilation support (17). Maintaining the ETT cuff pressure at $20-30 \mathrm{cmH}_{2} \mathrm{O}$ is an important element of care in airway management (18). It was found that the average age of the nurses participating in this study was similar to that of nurses in other studies in Turkey (16). In this study, while $21.9 \%$ of the nurses could answer the question related to a safe ETT cuff pressure range before the training, this percentage rose to $100 \%$ following the training. An investigation of similar studies revealed that $36 \%$ of the nurses responded to the question about recommended ETT cuff pressure with the answer ' $25 \mathrm{cmH}_{2} \mathrm{O}$ ', $32.0 \%$ gave the answer '20-30 $\mathrm{cmH}_{2} \mathrm{O}$ ' and $66 \%$ of them said they did not have any idea (15). It was also found that more than half of the ICU nurses had no knowledge about ETT cuff functions and safe ETT cuff pressure range (19). In a study in which 20 out of 30 supervising nurses were chosen randomly from general ICUs, the supervising nurses stated that they did not know the right maximum ETT cuff pressure (20). Another study revealed that only 15 out of 21 nurses working in a 13-bed ICU were aware of the fact that ETT cuff pressure could be controlled and only seven of these nurses reported that they knew the right maximum ETT cuff pressure (21). In a study conducted in Turkey, it was found that only $25 \%$ of nurses knew that the standard range of ETT cuff pressure is $20-30 \mathrm{cmH}_{2} \mathrm{O}$, and that $42.50 \%$ said this range was 10 $20 \mathrm{cmH}_{2} \mathrm{O}$, which revealed their lack of knowledge (16).

The limited knowledge of nurses regarding ETT cuff pressure which is revealed by research shows a parallelism with the literature. However, it was observed that training increased the ICU nurses' knowledge of ETT cuff pressure. By deepening their awareness of VAP prevention packages and the need to maintain ETT cuff pressure at $20-30 \mathrm{cmH}_{2} \mathrm{O}$, which is consistent with the clinical guidelines, potential complications may be prevented and patient safety may be increased.

Given the complications associated with low and high ETT cuff pressure, keeping the ETT cuff pressure at the appropriate level is essential for patient safety (15). 


\begin{tabular}{|c|c|c|c|c|}
\hline \multirow[b]{2}{*}{ Questions } & \multicolumn{2}{|c|}{ Pre-Training } & \multicolumn{2}{|c|}{ Post-Training } \\
\hline & $\begin{array}{l}\text { Correct } \\
\mathrm{n}(\%)\end{array}$ & $\begin{array}{l}\text { Incorrect } \\
\text { n (\%) }\end{array}$ & $\begin{array}{l}\text { Correct } \\
\text { n (\%) }\end{array}$ & $\begin{array}{l}\text { Incorrect } \\
\text { n (\%) }\end{array}$ \\
\hline \multirow{2}{*}{ ETT cuff pressure safe range } & $7(21.9)$ & $25(78.1)$ & $32(100)$ & $0(0)$ \\
\hline & \multicolumn{4}{|c|}{$Z=-5.000 p<0.001$} \\
\hline \multirow{2}{*}{$\begin{array}{l}\text { Development of microaspiration in low ETT cuff } \\
\text { pressure }\end{array}$} & $23(71.9)$ & $9(28.1)$ & $30(93.8)$ & $2(6.2)$ \\
\hline & \multicolumn{4}{|c|}{$Z=-2.333, p=0.020$} \\
\hline \multirow{2}{*}{ Development of VAP in low ETT cuff pressure } & $19(59.4)$ & $13(40.6)$ & $31(96.9)$ & $1(3.1)$ \\
\hline & \multicolumn{4}{|c|}{$Z=-3.207 p=0.001$} \\
\hline \multirow{2}{*}{$\begin{array}{l}\text { Leakage due to imperfect closure of the trachea by the } \\
\text { ETT cuff }\end{array}$} & $9(28.1)$ & $23(71.9)$ & $15(46.9)$ & $17(53.1)$ \\
\hline & \multicolumn{4}{|c|}{$Z=-1.414 p=0.157$} \\
\hline \multirow{2}{*}{ Tracheal damage in high ETT cuff pressure } & 28 (87.5) & 4 (12.5) & $31(96.9)$ & 1 (3.1) \\
\hline & \multicolumn{4}{|c|}{$Z=-1.342 p=0.180$} \\
\hline \multirow{2}{*}{ ETT cuff pressure control responsibility } & $20(62.5)$ & $12(37.5)$ & $31(96.9)$ & $1(3.1)$ \\
\hline & \multicolumn{4}{|c|}{$Z=-3.051 p=0.002$} \\
\hline \multirow{2}{*}{ Finger palpation of the pilot balloon technique } & $28(87.5)$ & $4(12.5)$ & $32(100)$ & $0(0)$ \\
\hline & \multicolumn{4}{|c|}{$Z=-2.000 p=0.046$} \\
\hline \multirow{2}{*}{ Minimal leak technique } & $10(31.2)$ & $22(68.8)$ & $30(93.8)$ & $2(6.2)$ \\
\hline & \multicolumn{4}{|c|}{$Z=-4.472 p<0.001$} \\
\hline \multirow{2}{*}{ Minimal obstructive volume technique } & $13(40.6)$ & $19(59.4)$ & $28(87.5)$ & $4(12.5)$ \\
\hline & \multicolumn{4}{|c|}{$Z=-3.638 p<0.001$} \\
\hline \multirow{2}{*}{ Intermittent measurement with manometer } & $11(34.4)$ & $21(65.6)$ & $31(96.9)$ & $1(3.1)$ \\
\hline & \multicolumn{4}{|c|}{$Z=-4.264 p<0.001$} \\
\hline \multirow{2}{*}{$\begin{array}{l}\text { Constant measurement with electronic or pneumatic } \\
\text { devices }\end{array}$} & $13(40.6)$ & $19(59.4)$ & $32(100)$ & $0(0)$ \\
\hline & \multicolumn{4}{|c|}{$Z=-4.359 p<0.001$} \\
\hline Inflation and deflation of the cuff every two hours in & $2(6.2)$ & $30(93.8)$ & $27(84.4)$ & $5(15.6)$ \\
\hline ETT cuff pressure damage prevention & $Z=-5.000$ & & & \\
\hline Aspiration of the in-mouth and subglottic areas in case & $29(90.6)$ & $3(9.4)$ & $30(93.8)$ & $2(6.2)$ \\
\hline the ETT cuff is deflated & $Z=-0.447$ & & & \\
\hline Effect of the patient's position on ETT cuff pressure & $18(56.2)$ & $14(43.8)$ & $26(81.2)$ & $6(18.8)$ \\
\hline & $Z=-2.138$ & & & \\
\hline Effect of the patient's internal temperature on ETT cuff & $12(37.5)$ & $20(62.5)$ & $31(96.9)$ & $1(3.1)$ \\
\hline pressure & $Z=-4.146$ & & & \\
\hline Effect of mechanical ventilator pressures on ETT cuff & $16(50)$ & $16(50)$ & $31(96.9)$ & $1(3.1)$ \\
\hline 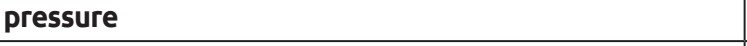 & $Z=-3.638$ & & & \\
\hline Effect of tracheal asniration on FTT cuff preseure & $20(62.5)$ & $12(37.5)$ & $19(59.4)$ & $13(40.6)$ \\
\hline 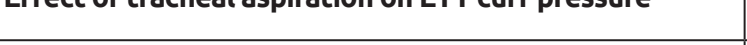 & $Z=-0.243$ & & & \\
\hline Effect of the natient's courahing on FTT cuff nrescure & $24(75)$ & $8(25)$ & $32(100)$ & $0(0)$ \\
\hline 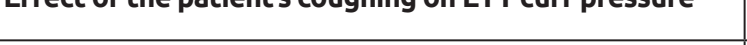 & $Z=-2.828$ & & & \\
\hline Effect of the patient's agitation on ETT cuff pressure & $20(62.5)$ & $12(37.5)$ & $30(93.8)$ & $2(6.2)$ \\
\hline 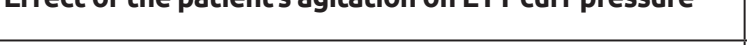 & $Z=-3.162$ & & & \\
\hline Effect of the patient's sedation on the ETT cuff & $27(84.4)$ & $5(15.6)$ & $16(50)$ & $16(50)$ \\
\hline pressure & $Z=-2.840$ & & & \\
\hline Average knowledae score over total points (20 Points) & $M \pm S D=1$ & & $\mathrm{M} \pm \mathrm{SD}=$ & 1.71 \\
\hline Aver dge knowieuge score over coldat poimis (zu roinis) & $Z=-4.942$ & & & \\
\hline
\end{tabular}




\begin{tabular}{|c|c|c|c|}
\hline & \multirow[b]{2}{*}{$\mathrm{n}(\%)$} & \multirow[t]{2}{*}{$\begin{array}{l}\text { Pre-Training } \\
\mathrm{M} \pm \text { SD }\end{array}$} & \multirow[t]{2}{*}{$\begin{array}{l}\text { Post-Training } \\
M \pm S D\end{array}$} \\
\hline & & & \\
\hline \multicolumn{4}{|l|}{ Age (years) } \\
\hline $18-23$ years & $12(37.5)$ & $10.83 \pm 0.70$ & $17.75 \pm 0.57$ \\
\hline 24-29 years & $11(34.4)$ & $10.63 \pm 0.99$ & $17.00 \pm 0.44$ \\
\hline \multirow[t]{2}{*}{30 years and over } & $9(28.1)$ & $11.33 \pm 0.88$ & $18.33 \pm 0.47$ \\
\hline & \multicolumn{3}{|c|}{$F=0.850 p=0.919$} \\
\hline \multicolumn{4}{|l|}{ Gender } \\
\hline Female & $19(59.3)$ & $11.05 \pm 0.54$ & $17.84 \pm 0.41$ \\
\hline \multirow[t]{2}{*}{ Male } & $13(40.7)$ & $10.96 \pm 0.90$ & $17.38 \pm 0.44$ \\
\hline & \multicolumn{3}{|c|}{$F=0.005 p=0.944$} \\
\hline \multicolumn{4}{|l|}{ Types of nursing degrees } \\
\hline Vocational school of health & $15(46.9)$ & $10.13 \pm 0.73$ & $17.46 \pm 0.50$ \\
\hline Associate Degree & $3(9.4)$ & $12.66 \pm 1.85$ & $16.66 \pm 0.33$ \\
\hline Bachelor's Degree & $9(28.1)$ & $11.33 \pm 0.94$ & $17.77 \pm 0.57$ \\
\hline \multirow[t]{2}{*}{ Post-Graduate Degree } & $5(15.6)$ & $11.40 \pm 0.81$ & $18.60 \pm 0.50$ \\
\hline & \multicolumn{3}{|c|}{$F=0.678 p=0.573$} \\
\hline \multicolumn{4}{|c|}{ Length of nursing experience (years) } \\
\hline $0-4$ years & 15 & $10.73 \pm 0.63$ & $17.66 \pm 0.48$ \\
\hline \multirow[t]{2}{*}{5 years and over } & 17 & $11.05 \pm 0.73$ & $17.64 \pm 0.39$ \\
\hline & \multicolumn{3}{|c|}{$F=0.065 p=0.800$} \\
\hline \multicolumn{4}{|l|}{ Type of ICU } \\
\hline Neurosurgery & $7(21.9)$ & $12.85 \pm 0.79$ & $16.85 \pm 0.96$ \\
\hline Anesthesiology and Reanimation & $6(18.8)$ & $10.83 \pm 1.13$ & $18.33 \pm 0.49$ \\
\hline Pulmonary Diseases & $5(15.6)$ & $10.40 \pm 0.97$ & $17.40 \pm 0.40$ \\
\hline Surgery & $4(12.5)$ & $11.00 \pm 2.00$ & $17.25 \pm 1.81$ \\
\hline Internal Diseases-Neurology & $3(9.4)$ & $10.00 \pm 1.15$ & $17.66 \pm 1.20$ \\
\hline Isolation & $3(9.4)$ & $7.66 \pm 1.66$ & $18.66 \pm 0.33$ \\
\hline Coronary & $2(6.2)$ & $13.00 \pm 0.00$ & $18.00 \pm 1.41$ \\
\hline \multirow[t]{2}{*}{ Cardiovascular Surgery } & $2(6.2)$ & $9.50 \pm 0.50$ & $18.00 \pm 1.00$ \\
\hline & \multicolumn{3}{|c|}{$F=1.394 p=0.253$} \\
\hline \multicolumn{4}{|l|}{ Length of ICU experience (years) } \\
\hline $0-4$ years & $19(59.3)$ & $10.73 \pm 0.64$ & $17.52 \pm 0.40$ \\
\hline \multirow[t]{2}{*}{5 years and over } & $13(40.7)$ & $11.15 \pm 0.74$ & $17.84 \pm 0.46$ \\
\hline & \multicolumn{3}{|c|}{$F=0.005 p=0.944$} \\
\hline \multicolumn{4}{|l|}{ Type of working shift } \\
\hline Only day or night Shift & $6(18.7)$ & $9.83 \pm 3.12$ & $18.16 \pm 1.47$ \\
\hline \multirow[t]{2}{*}{ Day and night shift } & $26(81.3)$ & $11.15 \pm 0.51$ & $17.53 \pm 0.34$ \\
\hline & \multicolumn{3}{|c|}{$F=1.324 p=0.259$} \\
\hline \multicolumn{4}{|c|}{ Length of one week working (hours) } \\
\hline $0-45$ hours & $16(50)$ & $11.06 \pm 0.52$ & $17.50 \pm 0.43$ \\
\hline \multirow[t]{2}{*}{46 hours and above } & $16(50)$ & $10.75 \pm 0.82$ & $17.81 \pm 0.43$ \\
\hline & $F=0.216$ & & \\
\hline
\end{tabular}


While high ETT cuff pressure leads to coughing, throat ache, hoarseness, haemoptysis, mucosal ischemia, tracheal damage, tracheal stenosis and fistula, low ETT cuff pressure causes microaspiration and development of VAP (2-4, 6-9). These complications extend the time the patients remain on a mechanical ventilator and in the ICU (16).

The study found no significant difference between pre-training and post-training knowledge levels regarding tracheal damage and the trachea not sealing completely due to deviant ETT cuff pressure, while there was a significant difference between the pre- and post- training knowledge of complications relating to microaspiration $(71.9 \%-93.9 \%)$ and VAP $(59.4 \%$ - 96.9\%). When similar studies were analyzed, it was seen that $95 \%$ of the nurses prevented ETT cuff leaks; $94 \%$ of patients of low ETT cuff pressure caused aspiration; $98 \%$ of patients of high ETT cuff pressure led to tracheal damage and $15 \%$ of patients resulted in difficulty in swallowing (15). In a study in Turkey, $78.80 \%$ of the nurses stated that tracheal necrosis occurred when the ETT cuff pressure was not right, and $28.8 \%$ pointed out that it could cause tracheal shrinkage (16). A continuous professional training on the effects of low or high ETT cuff pressure on patients is required.

There was no difference in the pre- or post-training knowledge level regarding air leakage during inflation when using the pilot balloon finger palpation technique, which the nurses implemented as the method of controlling ETT cuff pressure in the ICU. This can be explained as showing that the nurses knew the ETT cuff needs to be deflated and reinflated every two hours so as to prevent tracheal damage and remembered this when they were questioned.

The methods of ETT cuff pressure control are: palpation of the pilot balloon with finger (11), the minimal leak technique, the minimal obstructive volume technique (2), intermittent control with a manometer (3) and constant ETT cuff pressure control (12). Analyzing the literature regarding the methods of ETT cuff pressure control used, it is observed that the minimal obstructive volume technique is used in $10 \%$ of cases, the intermittent control with manometer is used in $76 \%$ of cases, the pilot balloon finger palpation technique is used in $41 \%$ of cases, and the constant control method is used in $0.3 \%$ of cases. The same study also found that $84 \%$ of nurses named the intermittent control with manometer technique as the most appropriate one (15). A study in Turkey revealed that $68.8 \%$ of nurses practiced control through finger palpation of the pilot balloon, $32 \%$ of them used the manometer to control ETT cuff pressure and $12.50 \%$ controlled it using the minimal leak technique. The minimal obstructive volume technique was not used by any nurses. Half of the nurses said that they inflated the ETT cuff until it had the consistency of an earlobe, $36.3 \%$ said they inflated the cuff with $10 \mathrm{ml}$ of air, $35.0 \%$ said they inflated until the sound of leakage died away and $2.5 \%$ said they inflated the cuff with $20 \mathrm{ml}$ of air. Meanwhile 5.3\% stated they did not know to what extent they were supposed to inflate it (16). It has recently been suggested in the literature that the most efficient method, particularly in preventing complications, is to constantly control constant the ETT cuff pressure with electronic, pneumatic, or smart-cuff manager $(3,22-27)$. There was a significant difference between the pre-training level of knowledge of the nurses and their posttraining level of knowledge. Since ETT cuff pressure control is mainly carried out using finger palpation of the pilot balloon in Turkey, it is clear that the answers mostly focused on this method. It was concluded that in addition to the fact that a shortage of knowledge existed in terms of ETT cuff pressure control, new developments in methods of control methods were not being monitored.

ETT pressure is affected by changes in position, internal body temperature, ventilator pressures and tracheal aspiration, mechanical ventilator moods, coughing, agitation, and sedation $(2,7)$. This study found a significant increase in the level of knowledge and correct answers regarding the factors affecting ETT cuff pressure. The higher number of correct answers regarding ETT cuff pressure range, control methods and potential complications which were given after the training suggested that nurses would be monitoring their patients better during their care.

The literature shows that face-to-face training and workshops devoted to the prevention of VAP lead to nurses maintaining normal ETT cuff pressure at a significantly higher level (28). $70 \%$ of the nurses in a Turkish study stated that they obtained their knowledge about ETT cuff pressure control from senior nurses and $89 \%$ of them felt that they needed ETT cuff pressure training as the knowledge they had obtained from senior nurses was not adequate (16).

\section{Limitations of The Study}

Because it was not a valid measurement tool, we used the self-developed instruments. Some of the nurses were unable to attend due to leave (annual leave, maternity leave, etc.). Also some of the nurses did not participate in the study because the care process continued in intensive care. As 
a result of the collaboration with the nursing services, the training could only be planned for one day.

\section{Conclusion}

It was observed in this study that the post-training level of knowledge of the nurses regarding ETT cuff pressure control methods was significantly higher than the pre-training level of knowledge. Feedback revealed that the training had educated the nurses about the normal values of ETT cuff pressure, complications in case the ETT cuff pressure deviated from normal, ETT cuff pressure control methods and the factors affecting ETT cuff pressure. It is believed that such training will increase the use and sustainability of the recommended ETT cuff pressure.

It was seen that ETT cuff pressure control training increased ICU nurses' level of knowledge, and that the nurses had positive opinions about it. In this regard, it is suggested that such training, aimed at enhancing the knowledge and skills of ICU nurses regarding ETT cuff pressure control, be repeated on a regular basis. 


\section{References}

1. Olgun N, Eti Aslan F, Çil Akıncı A. Toraks ve alt solunum sistemi hastalıkları. In: Karadakovan A, Eti Aslan F. editors. Dahili ve cerrahi hastalıklarda bakım. 2nd ed.Adana: Nobel; 2011. p. 419-428.

2. Sole ML, Penoyer DA, Su X, Jimenez E, Kalita SJ, Poalillo E, et al. Assessment of endotracheal cuff pressure by continuous monitoring: a pilot study. American Journal of Critical Care 2009;18:133-43.

3. Farré $R$, Rotger $M$, Ferre $M$, Torres $A$, Navajas D. Automatic regulation of the cuff pressure in endotracheally-intubated patients. European Respiratory Journal 2002;20:1010-3.

4. Nseir $S$, Lorente L, Ferrer M, Rouzé A, Gonzalez O, Bassi GL,et al. Continuous control of tracheal cuff pressure for VAP prevention: A collaborative meta-analysis of individual participant data. Annals of Intensive Care 2015; 5: 43.

5. Lorente L, Blot S, Rello J. Evidence on measures for the prevention of ventilatorassociated pneumonia. European Respiratory Journal 2007;30:1193-207.

6. Coffin SE, Klompas M, Classen D, Arias KM, Podgorny K, Anderson DJ, et al. Strategies to prevent ventilatorassociated pneumonia in acute care hospitals. Infection Control \& Hospital Epidemiology 2008;29:31-40.

7. Lizy C, Swinnen W, Labeau S, Blot, S. Deviations in endotracheal cuff pressure during intensive care. American Journal of Critical Care 2011;20:421-2.

8. Kapucu S, Özden G. Ventilatör ilişkili pnömoni ve hemşirelik bakımı. Hacettepe Üniversitesi Hemşirelik Fakültesi Dergisi 2014;1(1):99-110.

9. Uçgun I. Mekanik ventilasyon komplikasyonları. Yoğun Bakım Dergisi 2008:8:44-59.

10. Muallem M, El-Khatib MF. Automatic endotracheal tube cuff inflator and continuous pressure monitor/controller. Middle East Journal of Anesthesiology 2011;21:447-9

11. Liu J, Zhang X, Gong W, Li S, Wang F, Fu $\mathrm{S}$, et al. Correlations between controlled endotracheal tube cuff pressure and post procedural complications: a multicenter study. Anesthesia \& Analgesia 2010;111:1133-7.

12. Rouzé A, Nseir S. Continuous control of tracheal cuff pressure for the prevention of ventilator-associated pneumonia in critically ill patients: where is the evidence? Current Opinion in Critical Care 2013;19:440-7.

13. Yüceer $\mathrm{S}$, Bulut $\mathrm{H}$. Beyin cerrahi yoğun bakım ünitesinde çalışan hemşirelerin hastane enfeksiyonların önlenmesine ilişkin uygulamaları. Dicle Tıp Dergisi 2010;37:367-374

14. Baskan S. Postoperatif pnömoni: Önlem metodları ve destek tedavi. ANKEM Dergisi 2010;24(3):152-156.

15. Labeau SO, Bleiman M, Rello J, Vandijck DM, Claes B, Blot SI. Knowledge and management of endotracheal tube cuffs. International Journal of Nursing Studies 2015;52: 498-9.

16. Tekin $Y E$, lyigün $E$. Yoğun bakım ünitelerinde hemşirelerin trakeostomi/ endotrakeal tüp kaf basıncı uygulamalarının incelenmesi. Journal of Nursing Sciences 2016;8:26-33.

17. Jordan P, Van Rooyen D, Venter D. Endotracheal tube cuff pressure management in adult critical care units. Southern African Journal of Critical Care 2012;28:13-16.

18. Sole ML, Su X, Talbert S, Penoyer DA, Kalita $S$, Jimenez $E$, et al. Evaluation of an intervention to maintain endotracheal tube cuff pressure within therapeutic range. American Journal of Critical Care 2011;20:109-17.

19. Maboudi A, Abtahi H, Hosseini $M$, Tamadon A, Safavi E. Accuracy of endotracheal tube cuff pressure adjustment by fingertip palpation after training of intensive care unit nurses. Iranian Red Crescent Medical Journal 2013;15(5):381-4

20. Spittle CNS, Beavis SE. Do you measure tracheal cuff pressure? A survey of clinical practice. British Journal of Anaesthesia 2001;87:344-345.
21. Bhatta K, Greer R. Awareness and monitoring of tracheal tube cuff pressure in a multidisciplinary intensive care unit. Anaesthesia and Intensive Care 2007;35(2):302-303.

22. Kunitz $O$, Jansen $R$, Ohnsorge $E$, Haaf-vonBelow S, Schulz-Stübner S, Rossaint R. Cuff pressure monitoring and regulation in adults. Anaesthesist 2004;53(4):334-40.

23. Das $\mathrm{S}$, Kumar P. Comparison of minimal leak test and manual cuff pressure measurement technique method for inflating the endotracheal tube cuff. Indian Journal of Clinical Anaesthesia 2015;2(2):78-81.

24. Duguet A, D'amico L, Biondi G, Prodanovic H, Gonzalez-Bermejo J, Similowski, T. Control of tracheal cuff pressure: a pilot study using a pneumatic device. Intensive Care Medicine 2007;33(1):128-32.

25. Nseir S, Duguet A, Copin MC, De Jonckheere J, Zhang $M$, Similowski T, Marquette $\mathrm{CH}$. Continuous control of endotracheal cuff pressure and tracheal wall damage: A randomized controlled animal study. Critical Care 2007;11(5): 109

26. Valencia M, Ferrer M, Farré R, Navajas D, Badia JR, Nicolas JM, et al. Automatic control of tracheal tube cuff pressure in ventilated patients in semirecumbent position: a randomized trial. Critical Care Medicine 2007;35(6):1543-9.

27. Weiss M, Doell C, Koepfer N, Madjdpour C, Woitzek K, Bernet V. Rapid pressure compensation by automated cuff pressure controllers worsens sealing in tracheal tubes. British Journal of Anaesthesia 2009;102(2):273-8.

28. Yazdani M, Sabetian G, Ra' of S, Roudgari A, Feizi M. Comparative study of teaching clinical guideline for prevention of ventilator-associated pneumonia in two ways: face-to-face and workshop training on the knowledge and practice of nurses in the intensive care unit. Journal of Advances in Medical Education 2015;3(2):68-71. 